\title{
IMPLEMENTING THE PATHWAYS COMMISSION RECOMMENDED FIRST ACCOUNTING COURSE: A PROFILE OF EARLY ADOPTERS
}

\author{
Dr. Timothy G. Bryan \\ Assistant Professor \\ Lewis College of Business \\ Marshall University, Huntington, West Virginia, USA \\ E-mail: bryanti@marshall.edu \\ Dr. Mark A. McKnight \\ Associate Professor \\ Romain College of Business \\ University of Southern Indiana, Evansville, Indiana, USA \\ E-mail: mamcknight@usi.edu
}

\begin{abstract}
The primary purpose of the current research is to explore the extent to which schools and colleges of business have adopted Pathways Commission recommendations for a new first accounting course. This paper explores the extent to which schools of business and accounting programs have implemented curriculum revisions made by the Pathways Commission, as well as provide a profile of the early adopters of one of these recommendations. This study investigated common traits and characteristics of colleges and schools that had adopted the curricular changes. Specifically, the research focuses on the fourth recommendation from this list, which calls for a new first accounting course to be integrated into business and accounting programs. For the study, 68 faculty members from a cross-section of universities and programs answered questions about their institutions and the Pathways Commission recommended a new first course in accounting. Results indicate some ambivalence toward the curricular changes but also allowed for a profile of the early adopters of this specific change. Thus, the secondary purpose of the research is to identify environments in which the changes have been implemented and to provide a foundation for further research into best practices for implementing these types of curricular revisions.
\end{abstract}

Keywords: Accounting Curriculum, Accounting Education, Pathways Commission.

JEL Classification Codes: M40, M41, M49, I20.

\section{INTRODUCTION}

Formed by the American Accounting Association (AAA) and the American Institute of Certified Public Accountants (AICPA), the Pathways Commission on Accounting Higher Education established a goal to study the future of accounting education and develop recommendations for education "pathways." In its 2012 report, the Pathways Commission specified seven general recommendations for faculty, practitioners, and curriculum. This paper seeks to investigate the extent to which Recommendation \#4 has been adopted and/or implemented. Recommendation \#4 focuses on curriculum and faculty development. Specifically, the recommendation calls for the development of "curriculum models, engaging 
learning resources, and mechanisms for easily sharing them as well as enhancing faculty development opportunities in support of sustaining robust curriculum" (Pathways, 2012, p. 12).

The theme of the entire 2012 report is engagement between educators and practitioners. One specific result from Recommendation \#4 was to develop a new first-year accounting course utilizing best practices in education. The Pathways Commission (2012) recommends cooperation between accreditation bodies, education institutions, and practitioners to design a more effective introduction to accounting. A growing movement in accounting education has centered around the idea of overhauling the education of future accounting professionals (Albrecht \& Sack, 2000). Diller-Haas (2004) summarized the curriculum problem that continues to this day, writing "the old curriculum - which emphasizes memorization of accounting pronouncements and the mechanics of recording transactions - does not provide a complete picture of today's environment" (p. 60). Indeed, a common and long-standing problem is keeping curricula relevant as the profession changes and adopts new standards, goals, regulations, etc.

Madden and Phillips (1968) described accounting education to be an understanding of all aspects of business and others within the business: systems analysts, human resources, managers and all business fields. Accountants must be able to understand and explain a broad range of ideas in plain English and technical terms if required (Madden \& Phillips, 1968). Accountants and their standing are better if they are prepared to be business leaders and not simply focused on accounting education. This understanding should include the interrelationships between business, individuals, government, and society (Skousen, 1977).

While a theoretical framework to accounting education is occasionally the subject, more often practicing accountants must focus on skills, including writing, ethics, critical thinking, information technology, and analytical decision making. For practitioners, these skills must be set in the context of accounting knowledge (Pathways, 2015). Additionally, many believe practical experience in the field of accounting is essential before to graduate (Hurt, 2007). This practical experience could help accounting students understand why particular tasks are necessary.

The Commission (2012) addressed this concern by suggesting a revised first accounting course. The objective of a revised first accounting course would be two-fold: 1) Non-accounting majors should finish the course with a deeper appreciation of the critical role of accounting in business and society and 2) accounting majors should finish the course with an enhanced desire to become accountants and understand their role in the business (Pathways, 2012).

Studies in accounting education often indicate a gap between what universities teach in classes and what accountants need in practice (Gribbon \& Saini, 2016). Likewise, both the AAA and AICPA formed the Pathways Commission to address those (and other) concerns.

However, like the inertia mentioned by Shulman (2005), educational institutions are slow to change. Change requires the willingness to unlearn what has been done in the past, obtaining new information, and then learning a new method (Lewin, 1947). Schein (2010) points out that for individuals to be willing to quit doing what has been done in the past, there must first be anxiety or guilt created. In the case of a new first accounting course, the anxiety could be considered the Pathways Commission's (2012) recommendation which identified a need. However, individuals must also see that the anxiety created by the need for change is greater than the anxiety of learning a new method or initiating change (Schein, 2010). While a resistance to change can be found in virtually every organization, individuals may resist change even when faced with (1) change being in their own best interests, (2) a need exists, or (3) to avoid negative impact for themselves or their organization (Hultman \& Hultman, 2018).Resistance is the holding of unwillingness or unreceptiveness to change; readiness, 
however, is the holding of willingness or receptive to change (Hultman \& Hultman, 2018). Hultman and Hultman (2018) identify the feeling of stability in one's self as a key component of resistance and that individuals align themselves along a continuum of totally rigid to dynamic or adaptable.

In higher education the resistance to change may come from various sources: lack of awareness, the actual structure of higher education and lack of resources (Verhulst \& Lambrechts, 2015). Higher education institutions can be domains of conservative structure that are only minimally open to change (Verhulst \& Lambrechts, 2015). However, these discussions conflict with findings by McGuiness and Cronin (2016) that indicate a willingness to change increases with education level.

Given the known resistance to changes, particularly those related to curriculum updates, the present research sought to identify the types of higher education institutions that have implemented Pathways Commission Recommendation \#4. The study involved two stages: (1) exploratory interviews designed to identify constructs related to accounting education and (2) a survey that focused on change acceptance and adoption of Recommendation \#4.

\section{Research Questions}

Two research questions guided the data collection process. The first of these, essentially, served as an "opt-in" variable, which sought to identify if the institution was familiar with and had adopted the Pathways Commission recommendations (specifically Recommendation \#4). The secondary question, then, attempted to profile the types of institutions that have adopted the Commission's first new course proposal. Specifically, the research questions were:

- Have institutions modified their first course in accounting to more closely align with the Pathways Commission's 2012 recommendations?

- What are the key attributes of those universities that have implemented the Pathways Commission's curriculum changes?

\section{METHOD}

Exploratory interviews designed to identify constructs related to accounting education were conducted using a semi-structured interview process. Four accounting faculty members from four different schools and programs were selected to provide content validity to the survey questions and themes that would be developed for the second stage of the data collection process. Those selected were a convenience sample (not random).

The results of the interviews identified possible indicators of willingness to change or resistance to change. These themes included AACSB accreditation, professional certifications, and membership in AAA or AICPA. All appeared to be positively related to the implementation of the new accounting curriculum. Secondary issues identified older faculty and larger universities as possibly negatively related to implementing change. These are believed to be moderating factors of the primary factors related to change acceptance. Simple yes or no questions were asked within a survey. Size and age questions had grouped responses in five categories. Questions asked of interview participants are provided in Appendix A.

Next, the study adopted change acceptance scales developed by Holt (2007) and others. Personal confidence or learning anxiety (described as change self-efficacy in the scale) was measured utilizing the nine-point scale. Perceived need or survival anxiety and organizational benefit (both survival and learning anxiety) were both measured using their eight-point scales (Holt et al., 2007). These questions were asked in the survey with respondents asked to respond using a seven-point Likert scale. Six of the questions were 
reversed coded. All respondents were initially asked a similar qualifying question to those in the interviews, which identified if they either taught university accounting classes or oversaw a university accounting program. The specific questions asked are presented in Appendix B.

Finally, respondents were asked if they had adopted a new first accounting course. They were also asked three behavioral intention questions on a seven-point Likert scale, as adopted from Saaksjarvi and Morel (2010). These included:

- How positive or negative is your judgment of the curriculum changes suggested by the Pathways Commission?

- How interesting do you find the curriculum changes?

- How likely is it that you will implement the curriculum changes within two years from now? (If you have implemented changes, please mark extremely likely.)

\section{Participants}

The survey was sent to 210 people representing 107 universities, via email. A total of 68 individuals responded to the survey (a response rate of 32.3\%); with 65 of those 68 deemed to be "usable" (a practical response rate of 30.95\%). Approximately one tenured accounting faculty member and one non-tenured accounting faculty member were randomly selected from each university. Universities were selected from a combination of public and private universities in the Midwest.

Participants' teaching experience was varied, and although most groups were represented, the majority were experienced accounting faculty members. Ten of the participants had been teaching four years or less, another 10 had 5-9 years of experience, nine had 10-15 years of experience, and 36 participants had been teaching 15 years or more. This experience was reflected in participant ages as well, with only one participant under the age of 30, eight more were $30-39,14$ others were 40-49, 23 were 50-59 and 19 were aged 60 or more.

In addition to being experienced educators, most participants also possessed a relevant certification in the field of accounting. Specifically, $51(78.46 \%)$ of participants identified themselves as a Certified Public Accountant (CPA), Certified Management Accountant (CMA), or Certified Fraud Examiner (CFE). Approximately half (32, or 49.23\%) were members of the American Institute of Certified Public Accountants (AICPA), and a majority (49, or $75.38 \%$ ) were members of the American Accounting Association (AAA).

An overwhelming majority (57, or $89.06 \%$ ) were employed at schools where the business program was accredited by AACSB. Of those at AACSB affiliated programs, 39 maintained separate accounting accreditations through AACSB. A total of 14 universities represented had undergraduate enrollment of fewer than 5,000 students. Another 27 had between 5,000 and 15,000 undergraduates. Fifteen participants represented schools with $15,000-25,000$ undergraduate students and nine were at schools with an undergraduate enrolment of more than 25,000.

Very few participants (9, or 13.85\%) indicated their business programs had implemented a new first accounting course. Respondents were mixed about the overall degree of positive or negative impacts of the Pathways Commission suggestions for curriculum changes, though few viewed the suggestions as negative. Most were positive or indicated that the suggestions were neither positive nor negative $(94 \%)$. It should be noted that more than one-third of participants failed to categorize the suggested changes as positive or negative, and a relatively small portion (3, or 5\%) viewed the changes as somewhat negative. A vast majority found the proposed curricular changes as at least slightly 
interesting, with only $5 \%$ of respondents identifying the changes as "not interesting at all," and only $15 \%$ identified them as "slightly interesting."

Not only did participants find the proposed curricular changes interesting, but there is quite a bit of interest/intent to implement those changes. Many programs had already implemented (or were planning to implement) the proposed changes over the next two years. Of interest is that participants who had already implemented the suggested changes were asked to indicate "extremely likely" to this question. Additionally, over one-third of respondents indicated "neither likely nor unlikely"- this likely indicates a lack of familiarity with the recommendations. Only one-fourth of respondents considered the implementation of the proposed changes to be either somewhat or extremely unlikely.

Respondents generally agreed that there are legitimate reasons for their respective institutions to make the recommended curriculum changes. While a portion of the respondents was ambivalent towards the degree to which there were legitimate reasons for implementing the proposed changes by the Pathways Commission, less than $10 \%$ (5) disagreed that there was a legitimate rationale for making those changes.

In total, 35 respondents $(67.30 \%)$ agreed that legitimate reasons were making the curriculum changes. Additionally, respondents were split as to whether there had been explanations at their various institutions for why the changes must be made, with 22 $(42.31 \%)$ agreeing that no one had explained why the changes were needed, with another 13 (25\%) reporting that they neither agreed nor disagreed with the statement. Only 17 (32.69\%) reporting they had received explanations for why these proposed changes must be made. Even so, few $(8,15.68 \%)$ or reported disagreement with the idea that the curriculum change is clearly needed. Several were ambivalent, stating they neither agreed nor disagreed (17, or $33.33 \%$ ) while 26 others (50.98\%) agreed that the curriculum changes were needed.

In terms of rationale, a significant portion of respondents agreed there "real education needs" made curriculum changes necessary. While several participants were noncommittal (i.e., answered "neither agree nor disagree"), only 4 (or 7.7\%) disagreed with this statement. It should be noted that this question deals with curricular changes in general and does not specifically mention the Pathways Commission recommended curricular changes.

A majority of respondents (27 of 46, or 58.69\%) agreed that their respective university (or college) would benefit from implementing the curriculum changes suggested by the Pathways Commission. A considerable number of respondents did not agree or disagree $(15$, or $32.61 \%)$. Additionally, most participants indicated that their respective universities and schools would be better equipped to meet the needs of students and employers once the Pathways recommendations were adopted.

Additionally, participants were generally ambivalent when asked if the proposed curriculum change matches the priorities of their respective universities and colleges. Far more respondents $(22$, or $47.83 \%)$ agreed that the changes matched their institutions' priorities than did not agree (4, or $8.7 \%$ ), though a significant portion failed to assert a definitive opinion. This result was consistent with the number of respondents who indicated that the Pathways Commission recommendations would be an improvement over their institution's current practices.

When asked about personal gain on an individual level, results remained mixed, with high numbers of respondents neither agreeing nor disagreeing with various statements. While few felt that their futures would be limited because of these potential curriculum changes $(3$, or $6.98 \%)$, most disagreed (24, or $55.81 \%)$. Roughly one-third (16, or $37.21 \%$ ) failed to agree or disagree. Most also agreed with the statement that "in the long run, it will be worthwhile for me if the university adopts this curriculum change" 
The curriculum changes did not seem to make an impact as to the number of individuals who thought the changes would make their job easier. Only a relatively small portion agreed $(8$, or $18.61 \%)$ or disagreed $(12$, or $26.90 \%)$, while over half failed to agree or disagree $(23$, or $53.49 \%)$.

\section{Research Question One}

\section{RESULTS}

Research question one asked, "Have institutions modified their first course in accounting to more closely align with the Pathways Commission's 2012 recommendations?" Of the 68 responses, $22(32.35 \%)$ of them indicated that they either had implemented the recommended curriculum changes or expected to do so within two years. Of those 22 , only $4(18.20 \%)$ had implemented a new first accounting course.

A significant portion of respondents $(21$, or $30.90 \%)$ stated that implementing the proposed curriculum changes was neither likely nor unlikely, while only $15(22 \%)$ reported that it was either somewhat or extremely unlikely that the changes would be implemented within the forthcoming two years.

\section{Research Question Two}

Research question two asked "What are the key attributes of those universities that have implemented the Pathways Commission's curriculum changes?".To answer this question, only information taken from those participants who indicated they were likely to implement the curriculum changes within the next two years (or had already implemented them) was included in the analysis.

A significant number of institutions that were early adopters had faculty respondents who were experienced. Half of them (11, or 50\%) possessed 15 years of experience or more. Further details related to the experience of faculty at early adopter institutions are provided in Table 1.

Table 1. Faculty Teaching Experience at Early Adopter Institutions

\begin{tabular}{|c|c|c|}
\hline Number of Years Teaching & Number of Participants & Percentage \\
\hline $0-4$ & 4 & $18.20 \%$ \\
\hline $5-9$ & 5 & $22.7 \%$ \\
\hline $10-15$ & 2 & $9.10 \%$ \\
\hline $15+$ & 11 & $50.00 \%$ \\
\hline
\end{tabular}

In total, $81.90 \%$ of faculty respondents representing early adopter institutions had five or more years of teaching experience. Institutions that had experienced faculty appear more likely to be early adopters of the Pathways Commission recommendations than institutions with less experienced faculty.

Additionally, early adopter institutions were overwhelmingly represented by faculty who possessed professional certification. Specifically, $90.90 \%$ of respondents identified as Certified Professional Accountants (CPA), Certified Management Accountants (CMA), or Certified Fraud Examiners (CFE). Moreover, the faculty at early adopter institutions were engaged with the profession, with 50\% being members of the American Institute of Certified Public Accountants, while 95.50\% were members of the American Accounting Association.

Regarding accreditation, $95.50 \%$ of early adopter institutions were accredited by the Association to Advance Collegiate Schools of Business (AACSB). More specifically, 19 of those $21(90.48 \%)$ maintained separate accounting accreditation through AACSB. Most early 
adopter institutions had undergraduate enrollments of at least 5,000 students, as indicated in Table 2.

Table 2. Total Undergraduate Enrollment at Early Adopter Institutions

\begin{tabular}{|c|c|c|}
\hline Number of Undergraduate Students & Number of Participants & Percentage \\
\hline $0-4,999$ & 2 & $9.10 \%$ \\
\hline $5,000-9,999$ & 8 & $36.40 \%$ \\
\hline $10,000-14,999$ & 1 & $4.50 \%$ \\
\hline $15,000-19,999$ & 4 & $18.20 \%$ \\
\hline $20,000-24,999$ & 3 & $13.60 \%$ \\
\hline $25,000+$ & 4 & $18.20 \%$ \\
\hline
\end{tabular}

Faculty respondents for early adopter institutions tended $(90.90 \%)$ to be employed at institutions where there were at least five accounting faculty members. Table 3 provides specific details profiling the numbers of accounting faculty at early adopter institutions.

Table 3. Number of Accounting Faculty at Early Adopter Institutions

\begin{tabular}{|c|c|c|}
\hline Number of Accounting Faculty & Number of Participants & Percentage \\
\hline $0-4$ & 2 & $9.10 \%$ \\
\hline $5-10$ & 11 & $50.00 \%$ \\
\hline $11-20$ & 6 & $27.30 \%$ \\
\hline $21-30$ & 3 & $13.60 \%$ \\
\hline
\end{tabular}

\section{DISCUSSION}

Even when faced with a need for change, individuals will resist change with responses denying the need, stating the data does not apply to them personally or expecting special compensation for the change - maneuvering (Coghlan, 1996). As noted above Schein (2010) believes survival anxiety must exceed learning anxiety. However, he also states that learning anxiety must be reduced rather than increasing survival anxiety (Schein, 2010). Kotter (1995) believes people change for emotional reasons like Schein's (2010) anxiety reasons. He indicates change will occur if individuals are shown the benefits or need (Kotter, 1995). Sweeney and Horner (2012) also focus on establishing a clear vision or why before the change can occur in their pre-launch and launch phases. This clear vision indicates being ready for change. Less than one-third of respondents for the current study had implemented the proposed changes (or had direct intent to do so), even though significant portions of respondents saw benefits/needs for these specific changes.

Readiness is believed to be one of the most important factors in change (Armenakis, Harris, \& Feild, 1999). Holt, Armenakis, Harris, and Feild (2007) indicate that organization leaders introduce change to achieve specific goals. In this study, the leaders would be the Pathways Commission and the change in the suggested new course in accounting. For changes to happen, leaders must recognize that conflicts between their change and members of the group will happen (Holt et al., 2007). Leaders should address these or make the members ready for change (Holt et al., 2007). Without a clear vision or readiness, resistance (learning anxiety) becomes a barrier to change. For change to be implemented, leaders must understand why there is opposition to change and develop an effective response to the resistance (Smith, 2005). Current respondents indicate that more experienced and engaged faculty have tended to represent institutions that are early adopters of the Pathways Commission recommendations. 
To create change, communication that addresses stakeholders, reducing resistance, empowering those involve or impacted, and supporting the change process is needed (Lewis, et al., 2006). Kirkman and Rosen (1999) believe individual empowerment is key to change. Their key success factors are 1) believing the group can do well, 2) believing the group is performing important work, 3) believing the group has independence and discretion in completing the task, and 4) having a sense of importance that the work has an impact (Kirkman \& Rosen, 1999). Kotter and Schlesinger (2008) also cite the need for individual and group empowerment for change to be supported. Having faculty who are engaged in the profession is perhaps an element of empowerment that allows for accounting and business programs to adapt to needed changes more quickly, or perhaps makes them more willing to do so.

Wanberg and Banas (2000) identify several variables which impact readiness for change or openness to change: information on the change, participation in the change process, the belief to be able to do the change, social (organizational) support for change, and personal impact or benefit. Holt et al. (2007) continued with this thought process and developed four key factors for implementing change: personal confidence, perceived need (information), organizational benefit, and organizational support. They developed scales to measure these four variables which lead to organizational change (Holt et al., 2007). Di Fabio and Alessio (2016) confirmed the scales but modified them to the predisposition to change, support (organization), change-seeking, positive reaction to change (personal confidence), and cognitive flexibility. Due to the number of dimensions and difficulty in attempting to adapt the questions to curriculum change these scales were not utilized.

\section{Limitations \& Suggestions for Further Research}

The purpose of this paper is to provide an exploratory review into how (and perhaps why) the recommendations of the Pathways Commission have been adopted by accounting and business programs. The research does not attempt to offer meaningful explanations of why some universities have responded to the Pathways Commission's suggestions and some universities have not. Future research should consider the question of "why" particular schools, colleges, and institutions have been more (or less) likely to implement these, as well as other, curriculum changes.

The sample size is relatively small which could certainly impact the results. The sample could additionally have a bias due to the nature of the selection process and responses. An expanded sample could produce more meaningful comparisons and study relationships among variables more closely.

The concept of organizational support for change was not included, but previous studies have indicated a belief that the organization supports the change increases the likelihood of change acceptance and implementation (Kotter, 1995; Armenakis, Harris, \& Feild, 1999; Holt, et al., 2007; Sweeney \& Horner, 2012). Future research should measure organizational support for change as a potential factor concerning to the other variables and the degree to which the Pathways Commission recommendations have been implemented.

The results and findings from the present research provide an interesting profile of early adopters. Future research should expand upon the findings of the present study and test for relationships and predictive variables to create best practices for these, and other curricular revisions and improvements.

\section{CONCLUSION}

The AAA and AICPA's Pathways Commission (2012) recommendation \#4 includes the development of a first course in accounting with the goals of both giving non-accounting majors a deeper appreciation of the critical role of accounting in business and society and 
giving accounting majors an enhanced desire to become accountants and understand their role in business. As is discussed above, implementation of the new curriculum has been limited. However, the results indicate that well-informed survey participants (AACSB accredited schools, certifications, longer-tenured and members of professional organizations) are more likely to implement the changes suggested. Future work may need to focus on developing means of communicating the curriculum goals, recommendations and means of implementing to accounting faculty and administration to allow them to understand the implications, and effectively implement the recommendations.

\section{REFERENCES}

Albrecht, W. S., \& Sack, R. J. (2000). Accounting Education: Charting The Course Through A Perilous Future (Vol. 16). Sarasota, FL: American Accounting Association.

Armenakis, A. A., Harris, S.G., \& Feild, H.S. (1999). Making change permanent: A model for institutionalizing change interventions. In W. A. Pasmore \& R. W. Woodman (Eds.), Research in organizational change and development (Vol. 12, pp. 97-128). New York: JAI.

Coghlan, D. (1996). Mapping the process of change through organizational levels. Research in Organizational Change and Development, 9, 12-150.

Di Fabio, A., \& Alessio, G. (2016). Developing a New Instrument for Assessing Acceptance of Change, Frontiers in Psychology (7).https://doi.org/10.3389/fpsyg.2016.00802

Diller-Haas, A. (2004). Time to change introductory accounting. The CPA Journal, 74(4), 60 -62 .

Gribbin, D., \& Saini, J. S. (2016). Integrating practice into accounting education. Management Accounting Quarterly, 18(1), 1-I.

Holt, D., Armenakis, A. A., Harris, S. G., \& Field, H. S. (2007). Readiness for organizational change: The systematic development of a scale. The Journal of Applied Behavioral Science, 43(2) 232-255.

Hurt, B. (2007). Teaching what matters: A new conception of accounting education. Journal of Education for Business, 82(5), 295-299.

Hultman, K., \& Hultman, J., M. A. (2018). Self and identity: Hidden factors in resistance to organizational change. Organization Development Journal, 36(1), 13-29.

Kirkman, B. I., \& Rosen, B. (1999). Beyond self-management: Antecedents and consequences of team empowerment. The Academy of Management Journal, 42(1), $58-74$.

Kotter, J. P. (1995). Leading change: Why transformation efforts fail. Harvard Business Review. (March-April). 59-67.

Kotter, J. P., \& Schlesinger, L. A. (2008). Choosing strategies for change. Harvard Business Review. (July-August). 130-139. 
Lewin, K. (1947) Group decision and social change. In T.N. Newcomb and E.L. Hartley (Eds.), Readings in Social Psychology (pp. 459-473). New York: Holt, Rinehart and Winston.

Lewis, L. K., Schmisseur, A. M., Stephens, K. K., \& Weir, K. E. (2006). Advice on communicating during organizational change: The content of popular press books. Journal of Business Communication, 43(2), 1-25.

Madden, D. \& Phillips, L. (1968). An evaluation of the common body of knowledge study and its probable impact upon the accounting profession. Journal of Accountancy (February) 86-89.

McGuinness, S., \& Cronin, H. (2016). Examining the relationship between employee indicators of resistance to changes in job conditions and wider organisational change: Evidence from Ireland", Evidence-based HRM: a Global Forum for Empirical Scholarship, 1(4), 30-48. https://doi.org/10.1037/10.1108/EBHRM-042015-0013

Pathways Commission on Higher Education. (2012). The Pathways Commission on Higher Education: Chartering a national strategy for the next generation of accountants, American Accounting Association.

Sääksjärvi, M., \& Morel, K. P. N. (2010). The development of a scale to measure consumer doubt toward new products. European Journal of Innovation Management, 13(3), 272-293. https://doi.org/10.1037/10.1108/146010610110601200

Schein, E. H. (2010). Organizational culture and leadership. San Francisco, CA: JosseyBass-John Wiley \& Sons.

Shulman, L. (2005). Signature pedagogies within the professions. Daedalus, 134(3), 52-59.

Skousen, K. F. (1977). Accounting education: The new professionalism. Journal of Accountancy (July). 54-58.

Smith, I. (2005). Continuing professional development and workplace learning, 13. Resistance to Change - recognition and response. Library Management, 26 (8\&9). 519-522.

Sweeny, P., \& Horner, D. (2012). The proposed strategy change to embed energy stewardship into the Army's culture. Chambersburg, PA: U.S. Army Logistics Innovation Agency.

Verhulst, E. \& Lambrechts, W. (2015). Fostering the incorporation of sustainable development in higher education. Lesson learned from a change management perspective. Journal of Cleaner Production, 106. 189-205. https:// https://doi.org/10.1037/10.1016/j.jclepro.2014.09.049 
Wanberg, C. R., \& Banas, J. T. (2000). Predictors and outcomes of openness to changes in a reorganizing workplace. J. Appl. Psychol. 85, 132-142. https:// https://doi.org/10.1037/0021-9010.85.1.132

\section{APPENDICES}

Appendix A. Interview Questions

\begin{tabular}{|c|l|}
\hline $\begin{array}{c}\text { Question } \\
\text { Number }\end{array}$ & \multicolumn{1}{c|}{ Interview Question } \\
\hline 1 & $\begin{array}{l}\text { Just to be sure you are eligible to participate: Do you teach any } \\
\text { university-level accounting courses or oversee an accounting education } \\
\text { program (such as department head, program coordinator, dean, etc.)? }\end{array}$ \\
\hline 2 & How many years have you been teaching? \\
\hline 3 & What is your age? \\
\hline 4 & Are you a CPA, CMA or CFE? \\
\hline 5 & Are you a member of the AICPA? \\
\hline 7 & Are you a member of the American Accounting Association? \\
\hline 8 & Is your business program accredited by the AACSB? \\
\hline 9 & Does your accounting program have a separate AACSB accreditation? \\
\hline 10 & Has your business program implemented a new first accounting course? \\
\hline 11 & What is your university's undergraduate enrollment? \\
\hline
\end{tabular}

Appendix B. Survey Questions

\begin{tabular}{|c|l|}
\hline Question & \multicolumn{1}{c|}{ Survey Question } \\
\hline 1 & $\begin{array}{l}\text { I think the university (college) will benefit from this curriculum change. } \\
\text { Our university (college) is going to be more effective when we implement } \\
\text { this curriculum change. }\end{array}$ \\
\hline 3 & $\begin{array}{l}\text { When we adopt this curriculum change, we will be better equipped to meet } \\
\text { our students' and employers' needs. }\end{array}$ \\
\hline 4 & $\begin{array}{l}\text { This curriculum change will not improve our university's (college's) overall } \\
\text { effectiveness. }\end{array}$ \\
\hline 5 & $\begin{array}{l}\text { Our university (college) will lose some valuable assets (methodology of } \\
\text { teaching, faculty, etc.) when we adopt this curriculum change. }\end{array}$ \\
\hline 7 & $\begin{array}{l}\text { This curriculum change matches the priorities of our university (college). } \\
\text { This curriculum change replaces outdated aspects of the university (college) } \\
\text { while building on the positive attributes of the organization. }\end{array}$ \\
\hline 9 & $\begin{array}{l}\text { This curriculum change will be an improvement over our current practices. } \\
\text { When we implement this curriculum change, I can envision benefits coming } \\
\text { my way. }\end{array}$ \\
\hline 10 & $\begin{array}{l}\text { This curriculum change will disrupt many of the personal relationships I have } \\
\text { developed. }\end{array}$ \\
\hline 11 & \begin{tabular}{l} 
The prospective curriculum change will give me new career opportunities. \\
\hline When this curriculum change is implemented, I don't believe there is \\
anything for me to gain.
\end{tabular} \\
\hline
\end{tabular}




\begin{tabular}{|c|c|}
\hline 13 & My future in this position will be limited because of this curriculum change. \\
\hline 14 & $\begin{array}{l}\text { In the long run, I feel it will be worthwhile for me if the university (college) } \\
\text { adopts this curriculum change. }\end{array}$ \\
\hline 15 & $\begin{array}{l}\text { I am worried I will lose some of my status in the university (college) when } \\
\text { this curriculum change is implemented. }\end{array}$ \\
\hline 16 & This curriculum change makes my job easier. \\
\hline 17 & $\begin{array}{l}\text { The effort required to implement this curriculum change is rather small when } \\
\text { compared to the benefits I will see from it. }\end{array}$ \\
\hline
\end{tabular}

\section{Copyrights}

Copyright for this article is retained by the author(s), with first publication rights granted to the journal. This is an open-access article distributed under the terms and conditions of the Creative Commons Attribution license (http://creativecommons.org/licenses/by/4.0/). 